\title{
The State of American Federalism 2017-2018: Unilateral Executive Action, Regulatory Rollback, and State Resistance
}

\author{
Shanna Rose* and Greg Goelzhauser ${ }^{\dagger}$ \\ *Claremont McKenna College \\ †Utah State University; greg.goelzhauser@usu.edu
}

The state of American federalism in 2017-2018 is characterized by federal policy reversals, as the Trump administration and congressional Republicans continue to undo many of the Obama administration's policies. Two themes are highlighted in this essay. First, major policy changes continue to be undertaken primarily through unilateral executive action, even with Republicans holding the presidency and both the House and Senate. Ideological divisions within the Republican Party prevented Congress from enacting major legislation, save for a tax reform measure, and resulted in policy changes on health care, immigration, and the environment being made through executive and administrative action. Another prominent feature of governance in the early part of theTrump administration has been state resistance to federal directives, taking the form primarily but not exclusively of state attorney general (AG) lawsuits. Democratic AGs filed lawsuits challenging Trump administration actions on immigration and clean energy in particular. Democratic governors and state legislators also took a variety of other actions to resist Trump administration policies. The federal courts also continue to play an active role in shaping and adjudicating controversies impacting federalism.

The state of American federalism in 2017-2018 is characterized by federal policy reversals, as the Trump administration and congressional Republicans continue to undo many of the Obama administration's major policies ranging from the Affordable Care Act (ACA) to the Clean Power Plan. This development reflects the continuation of trends that emerged in the first few months of the Trump administration, when "the arrival of a new administration with radically different priorities" ushered in "broad policy reversals in arenas such as health care, immigration, and the environment, with potentially important implications for federalism and intergovernmental relations" (Goelzhauser and Rose 2017).

Two additional themes emerged in 2017-2018. First, unilateral executive action continued to play a prominent role in policymaking at the federal level despite unified Republican control of the federal government. With the exception of the 
Tax Cuts and Jobs Act that passed in December 2017, widening ideological divisions within the Republican Party prevented passage of major legislation and resulted in significant policy change occurring primarily through administrative action. As Republican lawmakers' efforts to repeal and replace the ACA succumbed to legislative gridlock, the Trump administration chipped away at the law by withholding Obamacare subsidies and announcing a variety of new rules making it easier for insurers to sell, and consumers to buy, insurance policies that do not comply with ACA regulations. As immigration reform stalled in Congress, President Trump issued a series of executive orders limiting entry to the United States from certain countries-orders that were quickly challenged in the courts. The administration also took steps to limit environmental protectionswithdrawing from the Paris Climate Agreement, ending the Clean Power Plan, and suspending the Clean Water Rule-and to reduce the size of Obama-era public lands designations.

A second emerging theme was state resistance to federal directives, primarily but not exclusively through a surge in state attorney general (AG) lawsuits. As discussed by Paul Nolette and Colin Provost in their article for this issue, 20172018 saw the continued — and accelerated-rise of litigation brought by attorneys general. Democratic state AGs brought scores of legal actions against the Trump administration over issues such as immigration and clean energy, following in the path of Republican AGs who filed lawsuits challenging Obama administration actions in these and other areas. In several of these cases, federal judges issued nationwide injunctions barring implementation of Trump administration actions. In cases filed or joined by state AGs, federal judges blocked enforcement of several of Trump's executive orders that restricted entry to the United States from certain countries and also blocked a Trump effort to reverse an Obama administration policy protecting certain unauthorized immigrants from deportation. Federal judges also sided with state AGs in ruling that the Trump administration could not reverse or delay enforcement of certain EPA regulations and could not alter the Obama administration's interpretation of the scope of the ACA's contraceptive coverage requirement.

Democratic governors and state legislators also took a variety of actions to resist Trump administration policies. In passing measures inconsistent with Trump administration policies, Democratic officials embraced a course of action pursued on a regular basis by Republican governors and state legislators during the Obama administration, as discussed by Adam Olson, Timothy Callaghan, and Andrew Karch in their article for this issue. California Governor Jerry Brown signed landmark "sanctuary state" legislation, limiting the cooperation of state and local law enforcement with federal immigration authorities-prompting a federal lawsuit against the state. Despite the Trump administration's rescission of Obama's hands-off marijuana policy vis-à-vis the states, Vermont became the 
ninth state to legalize recreational use of the drug, and the first to do so through the legislative process.

Blue-state lawmakers also drafted and occasionally enacted legislation making creative end-runs around other federal policies. State officials in the Northeast have been particularly intent on pushing back against a provision of the 2017 federal tax law that caps state and local tax deductions at $\$ 10,000$, disproportionately affecting Democratic-leaning states. Along with contemplating lawsuits challenging this change in federal tax law, state officials have considered various other means of passing legislation to limit the additional tax burden that the federal law imposes on residents of their states. States have also begun to respond to the Trump administration's reversal of the Obama administration's net-neutrality regulation, by enacting state net-neutrality laws that impose various regulations on internet service providers and thereby achieve the goals of the now rescinded Federal Communications Commission regulation. With Democratic control of state government at a low ebb-including only thirteen legislatures, sixteen governors, and twenty-two attorneys general-these actions reflect the vehement resistance of a remarkably small minority of state officials. Nonetheless, Democratic resistance to the Trump administration's agenda seemed to dominate the popular and political discourse, leading Merriam-Webster Dictionary to name "federalism" as one of the top ten words of the year in 2017.

\section{Public Policy}

The next several sections analyze federal and state policy developments in 2017 and early 2018, focusing on the areas featuring some of the most noteworthy federalism-related developments: health care, immigration, marijuana, education, and the environment.

\section{Health Care}

The spring and summer of 2017 saw the repeated failure of congressional efforts to repeal and replace the ACA, as Frank J. Thompson, Michael K. Gusmano, and Shugo Shinohara discuss in their article for this issue. Congressional leaders had initially hoped to push through a speedy repeal-only option following Trump's inauguration, but were stymied by resistance from some rank-and-file members and administration officials who feared political fallout from eliminating popular provisions such as the Medicaid expansion and regulations prohibiting insurance companies from discriminating against individuals with preexisting conditions. Throughout the spring, Congress considered a range of options including the Better Care Reconciliation Act, the so-called Skinny Obamacare Repeal, and the Graham-Cassidy bill, but each failed in turn. Despite controlling both chambers of Congress and the Oval Office, the Republican Party succumbed to internal 
ideological divisions, status quo bias, and the sheer complexity of the health care issue.

In the absence of congressional action to repeal the ACA, the Trump administration took a series of executive actions to undermine the law's efficacy. In October 2017, the White House announced that it would stop making the "costsharing reduction" payments to insurers that subsidize the purchase of insurance by millions of low-income Americans. In January 2018, the administration unveiled sweeping new rules allowing small businesses to join together to create "association" health plans that are exempt from the consumer protections mandated by the ACA. State officials joined with consumer groups and health insurers to oppose the measure, arguing that the inexpensive, skimpy plans would attract the youngest, healthiest workers-leaving older, sicker employees in traditional health plans and contributing to rising insurance premiums. In February 2018, the administration announced a new rule that makes it easier for consumers to buy inexpensive insurance policies that do not comply with ACA regulations by redefining "short-term, limited-duration insurance" as plans covering a period of less than one year; previously, such plans were defined as covering less than three months.

Congressional Republicans did enjoy a significant victory in their battle against the ACA in December 2017, when Congress passed and President Trump signed the most sweeping tax reform bill since 1986. Among other provisions, the new tax law eliminates the penalty imposed by the ACA's individual mandate, effective 2019. The Congressional Budget Office estimated that repealing the individual mandate penalty will reduce federal deficits by approximately $\$ 338$ billion between 2018 and 2027 and increase the number of uninsured people by 13 million in 2027 (U.S. Congressional Budget Office 2017).

Some Republican-led states also took individual actions to undermine the ACA's efficacy. To be sure, state officials' actions regarding the ACA have not always fallen along partisan lines, as Philip B. Rocco, Andrew S. Kelly, and Ann C. Keller demonstrate in their article for this issue analyzing state participation in the ACA's State Innovation Models initiative. On a number of other issues concerning ACA implementation, however, Republican state officials have been active in undercutting the law's effectiveness. Most notably, Idaho made headline news in January 2018 when Republican Governor C. L. "Butch" Otter issued an executive order instructing his state's insurance department to allow "creative options" in health coverage, free from "the overreaching, intrusive nature of Obamacare and its infringement on Idahoans' freedoms." The insurance department subsequently pronounced that as long as insurance companies offer at least one health plan that complies with ACA rules, they may defy the ACA in other ways, including selling low-cost policies that lack certain basic services, imposing yearly coverage limits, and discriminating against people with preexisting conditions. The Trump 
administration rejected Idaho's plan, however, explaining in a letter from CMS administrator Seema Verma that the ACA "remains the law, and we have a duty to enforce and uphold the law ... although it is certainly not our preference." However, the letter noted that "with certain modifications," the proposal might be acceptable, and encouraged the Otter administration to "continue to engage in a dialogue with [CMS] staff regarding this and other potential options" (Verma 2018).

In contrast, a number of Democrat-led states responded to federal efforts to dismantle the ACA by replacing or shoring up the law at the state level. Following the repeal of the federal individual mandate penalty, at least nine states considered passing laws that would require residents to have health insurance, although prospects for passage remained unclear at the time of writing (Armour 2018). As the Trump administration cut back on ACA marketing and outreach, some states invested heavily in efforts to enroll new individuals. And as the administration paved the way for stripped-down, short-term health plans, some states looked into tightening regulations on such plans. Whereas the ACA originally sought to reduce health disparities among states, such actions in certain states-and their absence in others-looked likely to further widen the health care gap (Sanger-Katz 2018).

In 2017-2018, Republican states continued to seek conservative new twists on the optional expansion of Medicaid under the ACA through the use of waivers. The scope for such efforts expanded in January 2018, when the Centers for Medicare and Medicaid Services (CMS) issued a letter to state Medicaid directors providing new guidance for waiver proposals under Section 1115 of the Social Security Act that would impose work requirements (referred to as "community engagement") as a condition of Medicaid eligibility—an option that had previously been firmly rejected by the Obama administration. Conservatives hailed the development as pro-work and anti-poverty, while liberals saw it as a thinly-veiled attempt to reduce coverage of vulnerable groups.

In early 2018, the Trump administration approved three states' waiver applications including work requirements. First, CMS approved a waiver application from the Republican Governor of Kentucky, Matt Bevin, titled "Kentucky Helping to Engage and Achieve Long Term Health" or KY HEALTH, in January 2018. In addition to a work requirement, the waiver included several other conservative provisions including premiums of up to four percent of incomegreater than the level approved in any other waiver to date-as well as coverage "lock-out periods" for a variety of reasons including nonpayment of premiums. Shortly thereafter, CMS approved a similar waiver application from Indiana, which had unsuccessfully sought approval of work requirements from the Obama administration in 2015. In March, CMS approved Arkansas's work requirement application, but deferred the state's request to reduce eligibility by lowering the income threshold from 138 percent to 100 percent of the poverty level. All three 
states planned to exempt Medicaid beneficiaries from the work requirement if they fall into certain categories such as disabled, pregnant, or primary caregiver, although the states' definitions of who meets these criteria varied.

Promptly after CMS approved KY HEALTH, Governor Bevin issued an executive order calling for the end of Kentucky's Medicaid expansion if the waiver were to be struck down in court. Undeterred, fifteen Kentucky Medicaid beneficiaries filed suit against the Trump administration in the case of Stewart $v$. Hargan (now Stewart v. Azar). The suit charged that Kentucky's recently approved waiver violates the Secretary of HHS's authority under the Social Security Act, because it is not an experimental project consistent with the objectives of the Medicaid Act. As Sara Rosenbaum observed, the recently approved waivers represent a dramatic departure from those approved by previous administrations, which had balanced risks, such as those arising from spending curbs, against gains, such as enrollment expansions. Moreover, this strategy for "selectively culling the Medicaid population" was particularly striking as it was "set to unfold against perhaps the nation's most successful ACA Medicaid expansion"-championed by Governor Bevin's predecessor, Democrat Steve Beshear-under which upwards of 400,000 people gained coverage (Rosenbaum 2018).

Several other states have expressed an interest in Medicaid work requirements. As of March 2018, seven Republican-led states-Arizona, Kansas, Maine, Mississippi, New Hampshire, Utah, and Wisconsin-had pending waiver applications featuring work requirements as a condition of eligibility (Musumeci et al. 2018). Utah's application in particular received attention because, like Arkansas's deferred request, it also sought to reduce eligibility from 138 percent to 100 percent of the federal poverty level while continuing to receive the same federal contribution rate. A few other states, including Oklahoma and Florida, mulled the possibility of following suit with work-requirement waiver applications of their own. Meanwhile, an investigation by the Government Accountability Office found that there has been insufficient federal and state oversight of Medicaid waivers, and that waiver evaluations have "generally lacked rigor" and suffered from "significant methodological weaknesses," calling into question the growing use of waivers to dramatically remake the Medicaid program (U.S. GAO 2018).

The ongoing opioid crisis in the United States prompted governors to join with medical providers and health-care advocates in pushing Congress to repeal a longstanding rule that limits states' ability to use Medicaid to fund care for opioid addiction. The so-called "Institutions for Mental Diseases (IMD) Exclusion" restricts Medicaid payments to facilities with more than sixteen beds from providing substance abuse treatment, reflecting the federal government's efforts, around the time of Medicaid's enactment, to deinstitutionalize mental-health patients and integrate them into communities. The push to repeal the rule represents a rare instance of bipartisan consensus among governors. In the absence 
of congressional action, the Trump administration granted waivers allowing two states (Kentucky and West Virginia) to get around the IMD exclusion, and signaled its openness to considering additional applications.

\section{Immigration}

Immigration federalism remains at center stage in the policy arena, as described more fully by Gary M. Reich in his article in this issue. Many of the most pressing issues are embroiled in ongoing litigation. Federal courts enjoined the first two iterations of President Trump's executive orders in early 2017 limiting entry from certain countries. The Supreme Court in June 2017 agreed to review the validity of the second executive order, but this order expired and the case was dismissed from the docket. Upon the second executive order's expiration, President Trump in September 2017 issued Proclamation 9645 (2017) limiting entry from nationals of Chad, Iran, Libya, North Korea, Syria, Venezuela, and Yemen (though Chad was removed in April 2018). After the U.S. Court of Appeals for the Ninth Circuit largely upheld but narrowed a district court's injunction against this third version of the travel ban, the Supreme Court again granted review and the case is set for oral argument in April 2018. The Court granted certiorari to address several questions, including whether the claims are justiciable, whether the proclamation falls within the president's statutory and constitutional authority, and whether it violates the First Amendment's Establishment Clause.

Policies concerning so-called "sanctuary" jurisdictions continue to raise important federalism issues. As municipal governments continue to adopt policies that limit cooperation with federal law enforcement officials with respect to immigration, several states have moved to limit local government authority in this area. Most prominently, Texas enacted legislation in 2017 preventing local entities from passing policies that "prohibit[] or materially limit[] the enforcement of immigration laws" (Texas Senate Bill 4 [2017]). Moreover, the bill commands local law enforcement to "comply with, honor, and fulfill" ICE detainer requests (Texas Senate Bill 4 [2017]). The City of El Cenizo initiated litigation alleging, among other claims, that federal law preempts the bill; that it violates the U.S. Constitution's First and Fourteenth Amendments; and that it violates separation of powers and home rule provisions of the Texas Constitution. After a federal district court initially enjoined enforcement of parts of the law (City of Cenizo v. Texas, No. SA-17-CV-404-OLG [2017]), the Fifth Circuit stayed part of the injunction (City of Cenizo v. Texas, No. 17-50762 [2017]) and litigation to resolve the case on its merits is in progress. Moving in the other direction, several cities in California are poised to sue the state in an effort to secure exemptions from its sanctuary policies (Holder 2018), which are discussed in more detail below. 
Litigation is also ongoing regarding Executive Order 13768 (2017), where President Trump stated intent to deny federal funds to jurisdictions that do not comply with federal immigration law. In the most thorough decision on the merits to date, a federal district court in California enjoined enforcement of the order, finding that plaintiff municipalities are likely to prevail in arguing that the order is unconstitutional (County of Santa Clara v. Trump, 250 F. Supp. 3d 497 [2017]). Specifically, the court indicated that municipalities were likely to succeed in arguing that the order violated the separation of powers; usurps congressional spending authority; violates the Spending Clause, even if the president had that authority; violates the Tenth Amendment's prohibition on commandeering local officials; and violates the Fifth Amendment's Due Process Clause as a result of various ambiguities, including a lack of clarity on what constitutes a "sanctuary" jurisdiction and what actions would constitute violations of the order. Aside from the merits, this litigation poses potentially interesting justiciability questions given that the order has not yet been enforced. In County of Santa Clara v. Trump, the district court argued that it was sufficient that municipal policies were inconsistent with the order, that there was expressed intent to enforce the order, and that budgetary uncertainty constituted sufficient injury.

Meanwhile Congress continues to consider legislation aimed at thwarting sanctuary jurisdictions. In 2017, the House passed the "No Sanctuary for Criminals Act" (H.R. 3003). It declares that no governmental entity or individual may "prohibit or in any way restrict" efforts to comply with federal immigration law. While Senate passage is less likely in its current partisan configuration, President Trump continues to lobby for action. In his weekly address on March 10, 2018, he said, "Sanctuary jurisdictions are the best friend of smugglers, gang members, drug dealers, human traffickers, killers, and other violent offenders. We want our cities to be sanctuaries for Americans, not safe havens for criminals. That is why I am calling on Congress to block funds for jurisdictions that shield dangerous criminals."

On March 6, 2018, the Trump administration brought suit against California arguing that federal immigration law preempts recently enacted California legislation limiting the ability of employers to provide nonpublic access to the workplace without a warrant for immigration enforcement purposes, directing the state AG to inspect facilities holding immigration detainees, and limiting state and local cooperation with federal immigration enforcement. In its initial complaint, the administration argued that these statutes "reflect a deliberate effort by California to obstruct the United States' enforcement of federal immigration law, to regulate private entities that seek to cooperate with federal authorities consistent with their obligations under federal law, and to impede consultation and communication between federal and state law enforcement officials" (Complaint 2018 , 2). Consistent with how changing partisan perspectives have driven recent 
federalism debates more broadly (Goelzhauser and Rose 2017), the tenor of this litigation resembles questions resolved by the Supreme Court in Arizona v. United States, 132 S. Ct. 2492 (2012), where the Obama administration successfully argued that antiimmigration laws in Arizona were preempted by federal immigration law.

Judicial proceedings also continue in the dispute over the Deferred Action for Childhood Arrivals (DACA) policy. Announced by President Obama in 2012, DACA allowed certain individuals who entered the country as minors and remained undocumented to receive renewable two-year permits and avoid deportation. After President Obama in 2014 sought to expand the program, by putting in place a Deferred Action for Parents of Americans and Lawful Permanent Residents (DAPA) program, numerous states challenged the validity of the DAPA order. The Supreme Court ultimately affirmed an injunction against DAPA by an equally divided vote after Justice Scalia's passing (United States v. Texas, 136 S. Ct. 2271 [2017]). When President Trump moved to end DACA, numerous states, municipalities, and other entities brought suit raising various claims, including that the rescission violated the Administrative Procedure Act, the Fifth Amendment's Due Process Clause, and the Fourteenth Amendment's Equal Protection Clause. Finding that plaintiffs were likely to succeed on the merits of the claim that rescission was arbitrary and capricious and thus invalid under the Administrative Procedure Act, a federal district court mandated that the program be continued (Regents of the University of California v. United States Department of Homeland Security, 3: 17-cv-05211 [2018]). Subsequently, the Supreme Court denied the government's request for expedited review and further litigation is pending. Simultaneously, Congress continues to discuss legislative reform.

\section{Marijuana}

Marijuana policy was characterized by growing federal-state conflict in 2017-2018. In January 2018, U.S. AG Jeff Sessions rescinded a triad of Obama administration memos that had established a hands-off policy with regard to state laws legalizing marijuana. The Obama administration memos, issued by Deputy Attorneys General David Ogden and James Cole, had stated that although marijuana remained illegal at the federal level, federal prosecutors should place low priority on prosecuting growers, sellers, and consumers as long as they complied with state laws. Calling the change in policy a "return to the rule of law," Sessions instructed "federal prosecutors deciding which cases to prosecute to weigh all relevant considerations of the crime, the deterrent effect of criminal prosecution, and the cumulative impact of particular crimes on the community" (Sessions 2018). However, Sessions later clarified that federal law enforcement lacks the resources to 
prosecute "small" or "routine" cases, and would instead continue to focus on drug gangs and other major cases (Gurman 2018).

Political leaders in states where marijuana is legal denounced the change in federal guidance. California Lieutenant Governor Gavin Newsom complained that the Trump administration had "destructively doubled down on the failed, costly and racially discriminatory policy of marijuana criminalization, trampling on the will of California voters" (Newsom 2018). Oregon Governor Kate Brown called the reversal "deeply concerning and disruptive to our state's economy," and protested that "voters in Oregon were clear when they chose for Oregon to legalize the sale of marijuana and the federal government should not stand in the way of the will of Oregonians" (Brown 2018). Many state leaders complained that they had not been consulted or notified in advance about the change.

Sessions also sent a letter to congressional leaders in 2017, asking them to repeal the Rohrabacher-Blumenauer (formerly Rohrabacher-Farr) Amendment, which since 2014 has blocked the Justice Department from using federal tax dollars to prosecute states where medical marijuana is legal. However, after two brief government shutdowns and considerable budgetary uncertainty, Congress finally hammered out a budget deal that preserves the amendment, at least for the time being.

In stark contrast to the Trump administration's efforts to crack down on marijuana, public opinion polls indicated record high support for legalization of the drug. According to an October 2017 poll by Gallup, 64 percent of Americans say the drug should be legal - the highest level of support in the nearly five decades Gallup has been polling on the topic. Although a partisan divide remains, with 72 percent of Democrats favoring legalization compared to 51 percent of Republicans, 2017 was the first time a majority of Republicans have expressed support for legalization. The 51 percent approval rate reflects a sizeable nine percentage-point increase relative to the previous year. As the Gallup report observed, "Attorney General Jeff Sessions could find himself out of step with his own party if the current trends continue" (Gallup 2017).

State and local efforts to legalize marijuana progressed in 2017-2018. Most notably, Vermont became the ninth state to legalize recreational use of the drugand the first to do so through the legislative process. ${ }^{1}$ After the state's Democratcontrolled legislature passed the bill, Republican Governor Phil Scott signed it into law with "mixed emotions," observing: "A number of states have already legalized it surrounding us. Whether we like it or not, it's here and it's being utilized, so we have to take steps to promote the general public" (Sanders 2018). Reflecting a bipartisan compromise, the Vermont law does not go as far as those of other states that have legalized marijuana. It allows individuals aged twenty-one years and over to possess one ounce and to grow up to two plants at home, but does not permit a legal retail market for the drug. 
Vermont's law set an important new precedent that the Democratic leaders of several other states signaled they wished to emulate. New Jersey's new governor, Democrat Phil Murphy, campaigned on the issue and, upon taking office, expressed his desire to sign legislation legalizing marijuana during his first year. As of spring 2018, a bill to legalize the possession and use of small amounts of the drug and establish a legal retail market was under consideration in the state legislature, but prospects for passage were murky due to ambivalence or opposition among lawmakers of both parties. Rhode Island's Democrat-controlled general assembly set up a commission to study legalization, and Delaware's Democratcontrolled general assembly established a task force to do the same. Meanwhile, advocates in a handful of other states including Michigan and Ohio pushed to get recreational marijuana on the 2018 ballot.

Legalization of recreational marijuana in California, passed by ballot measure in 2016, went into full effect on January 1, 2018, when recreational sales became legal for the first time. Although the law allows adults twenty-one and older to possess up to one ounce of the drug and to grow up to six plants at home, the state's antitobacco laws prohibit residents from smoking the drug in public. Despite marijuana's new legal status within the state, some local governments moved to regulate or ban its sale and use. Four of the state's largest cities-Los Angeles, San Diego, San Jose, and San Francisco-allow recreational cannabis shops, but many other localities including Bakersfield and much of Orange County ban all marijuana businesses. The result is "a rapidly evolving patchwork of rules that can vary widely from one city to the next" (Staggs 2018).

Implementation of 2016 ballot measures legalizing recreational marijuana in two other states-Massachusetts and Maine-was slower, following months of deliberations over rules and regulations governing sale of the drug. Massachusetts's Cannabis Control Commission finalized its rules in March 2018, paving the way for retail sales to begin in July. In Maine, Republican Governor Paul LePage vetoed the legislature's first bill to regulate marijuana sales in 2017, arguing that it conflicted with federal law, was inconsistent with the state's medical marijuana program, and created "a bifurcated regulatory structure with two Executive Branch departments regulating the market, which is almost certain to create unnecessary additional administrative costs and confusion," among other concerns (LePage 2017). In 2018, state lawmakers set to work drafting a revised bill, but its prospects for passage and avoiding another gubernatorial veto remained unclear.

Lawmakers in several states including California, Alaska, and Massachusetts responded to the Trump administration's reversal of Obama-era protections for states that have legalized marijuana by considering bills that would provide "sanctuary status" for licensed cannabis businesses. Borrowing an idea from the recent state and local movement to protect undocumented immigrants, the 
measures would prohibit the use of state or local resources to assist in federal drug enforcement efforts, in the absence of a court order, targeting businesses or individuals who are in compliance with state marijuana laws. Berkeley, California, passed a resolution making it a marijuana sanctuary city in February 2018.

Efforts to legalize medical marijuana and decriminalize possession of small amounts of the drug also inched forward. West Virginia became the twenty-ninth state to legalize the use of marijuana for certain medical conditions in 2017; the law only applies to cannabis-infused products, excluding smokable marijuana. Several other states including Kentucky, Oklahoma, South Dakota, Utah, and Missouri mulled legalization of medical marijuana in 2018, either through legislation or ballot initiatives (Sanders 2018). Although decriminalization of marijuana stalled in Alabama, several cities including Atlanta, Albuquerque, and Kansas City decriminalized the possession of small amounts of the drug. And San Francisco moved to automatically dismiss all marijuana misdemeanor convictions dating back to 1975 and clear the records of individuals who faced such charges.

\section{Education}

The Trump administration's efforts to scale back the role of the federal government in education policy continued in 2017-2018. One area in which this shift was particularly apparent was school accountability. The Every Student Succeeds Act (ESSA), signed by President Barack Obama in 2015, replaced No Child Left Behind and diminished the federal role in improving or closing lowperforming schools by allowing states to establish their own accountability systems. In early 2017, congressional Republicans further reduced the federal role by rescinding Obama-era regulations clarifying how states should measure schools' performance and hold low-performing schools accountable under the law. U.S. Secretary of Education Betsy DeVos subsequently released a scaled-back application template for states to use in developing their accountability plans that included fewer requirements than before, particularly with regard to soliciting input from the education community. She said the new guidelines would allow states and districts to implement the law with "maximum flexibility," but a variety of stakeholders including the National Governors Association, American Federation of Teachers, and National PTA expressed disapproval (Klein 2017).

The process by which the Department of Education vetted state accountability systems in late 2017 and early 2018 was turbulent. In approving thirty-five states' plans while sending others' back for revisions, DeVos vexed both congressional Democrats, who accused the Education Department of rubber-stamping inadequate plans, and Republicans eager for maximum state flexibility. Education and civil rights groups joined Democrats in criticizing the approval of state plans that inadequately measured the performance of certain groups such as 
minority students and inadequately enforced improvement for those groups (Camera 2018). DeVos responded by pointing her finger back at the states for failing to take full advantage of the new freedom they had been afforded by innovating in educational programming. Complaining about "too many plans that only meet the bare minimum required by the law," DeVos nonetheless vowed not to fall into the "trap of a top-down approach" that had been pursued by her predecessors (DeVos 2018).

Another area characterized by federal policy reversals and federal-state conflict was Title IX of the Education Amendments of 1972, a federal civil rights law that prohibits discrimination on the basis of sex in any educational program that receives federal funding. In February 2017, the Trump administration revoked an Obama-era guidance letter specifying that public schools should allow students to use bathrooms that align with their gender identity. In rescinding the guidance, DeVos and Sessions said that Title IX did not compel schools to allow transgender students to use the bathroom of their choice, and argued that states and school districts should be permitted to determine how to best accommodate the needs of transgender students. Civil rights groups criticized the move as leaving transgender students susceptible to aggression and violence. One year later, the Education Department confirmed that it had dismissed several civil rights complaints from transgender students who had been prohibited from using school bathrooms matching their gender identity, and clarified that it did not plan to hear or take action on such complaints.

The Education Department rescinded another Obama-era Title IX guidance letter when it offered new guidelines on how schools should respond to allegations of sexual assault. In September 2017, the Trump administration replaced Obama's 2011 "Dear Colleague" letter with a "Q\&A on Campus Sexual Misconduct" stating that to protect due process for the accused, schools could use a more rigorous standard of proof known as "clear and convincing evidence" instead of the "preponderance of the evidence" standard that had been advanced by the Obama administration (U.S. Department of Education 2017). The new guidance also allowed schools to pursue informal resolutions such as mediation if both parties agree to it, and to establish an appeals process. The move drew both praise and criticism from various groups, but many campuses indicated that it would have little effect on their sexual assault policies.

Following the February 2018 mass shooting at Marjory Stoneman Douglas High School in Parkland, Florida, public pressure mounted for new federal and state policies to promote school safety. In March, the Florida Legislature passed sweeping bipartisan legislation that, among other measures, funded additional school security and mental health personnel and permitted certain staff members to carry guns in schools. Subsequently, several other states mulled similar measures. Florida is not the first state to allow teachers to carry guns, although 
many educational groups including the National Education Association and American Federation of Teachers are opposed to the policy (Hobbs and Brody 2018). For its part, the White House announced a few token measures-including the creation of a school safety commission led by DeVos and a pledge to fund firearm training to school personnel through the Department of Justice-but otherwise left policy changes up to states and school districts, calling school safety "a state and local issue" (Camera 2018).

\section{Environment}

The Trump administration continues to take steps to limit environmental protections. As David M. Konisky and Neal D. Woods explain more fully in this issue, the federalism implications have been striking. In June 2017, the administration announced that it would withdraw from the Paris Climate Agreement. The agreement is a global pact to reduce emissions and manage the global average temperature to counteract climate change. Examples of important regulatory maneuvers include the October 2017 announcement that the administration would end the Clean Power Plan and January 2018 suspension of the Clean Water Rule. The former is an Obama-era regulation that seeks to reduce carbon dioxide emissions, while the latter subjects certain waterways to regulation under the Clean Water Act.

One emerging federalism dispute involves the Corporate Average Fuel Economy (CAFE) standards. By regulating vehicle fuel efficiency standards, the CAFE standards are widely considered to be an important tool for mitigating emissions and greenhouse gases. Three recent events surrounding the CAFE standards are notable. First, in a lawsuit brought by five states among other entities, the U.S. Court of Appeals for the Second Circuit vacated the administration's decision to delay implementation of an Obama-era rule to increase noncompliance penalties, which had eroded over time through inflation (National Resources Defense Counsel v. National Highway Traffic Safety Administration, 17-2780 [2018]). Second, in a move "sure to spark major political and legal battles," the administration announced that it would revoke Obama-era standards mandating certain vehicles to average more than fifty miles per gallon by 2025 (Eilperin and Denis 2018). Third, as discussed in detail in last year's Annual Review (Goelzhauser and Rose 2017, 299-300), California's preemption waiver to adopt more stringent emission standards - which in turn have been adopted by numerous states-were thought to be one of the administration's key targets for regulatory rollback. While announcing a plan to revise CAFE standards, Administrator Pruitt declared, "EPA will set a national standard for greenhouse gas emissions that allows auto manufacturers to make cars that people both want and can afford-while still expanding environmental and safety benefits of newer cars" (Kulish 2018). 
Referring to California's waiver specifically, Pruitt added, "Cooperative federalism doesn't mean that one state can dictate standards for the rest of the country" (Kulisch 2018).

States and municipalities are combatting efforts to limit environmental protection in several additional ways. During the Trump administration's first year, Democratic state attorneys general brought dozens of legal actions over issues such as clean energy, pollution, and federal lands (Grandoni 2018). In February 2018, for example, New York led a coalition of eleven states challenging the Clean Water Rule's suspension as a violation of the Administrative Procedure Act. In the complaint, plaintiff states argued that the suspension "harms the States' waters by limiting the [Clean Water] Act's protections and by making implementation of the Act more difficult," while also impos[ing] economic burdens and costs upon the States and harm[ing] their proprietary interests" (Complaint 2018, 4). Litigation over the Clean Power Plan also remains active.

Aside from litigation, states and municipalities are taking a variety of steps toward enhancing environmental protection. After the Trump administration announced withdrawal from the Paris Climate Agreement, numerous governmental entities pledged support for the agreement (Jordans and Thiesing 2017). At the state level, California continues to lead the way toward enhanced environmental protection, aggressively pursuing emissions cuts while outlining new strategies in areas such as renewable power and transportation (e.g., Plumer 2017). Legislative leaders in Oregon are hoping to pass a cap on greenhouse gas emissions in 2019 (Selsky and James 2018). And while the effort failed, Washington's Governor Jay Inslee pursued "the nation's first tax on planet-warming carbon dioxide pollution" in what may have been a play for visibility as a Democratic candidate for president in 2020 (Davenport 2018). At the municipal level, New York City sued oil companies such as BP, Chevron, and ExxonMobil to recover for alleged past and future injuries resulting from company actions that may have contributed to climate change (Mooney and Grandoni 2018).

The administration's efforts to drill for oil and gas have also generated federalism controversies. In January 2018, the Trump administration announced a proposal to permit drilling for oil and gas in various waters comprising the outer continental shelf. The proposal was met with immediate disapproval from various state leaders, and Interior Secretary Ryan Zinke emphasized that "states, local communities and congressional delegations will all have a say" (Fears 2018). A few days later, Secretary Zinke met with Florida's Republican Governor Rick Scott, who earlier announced opposition to the proposal, and declared the state "unique" and "off the table" with respect to coastal drilling (Bousquet 2018). This exemption led politicians from other states to seek exemptions, and several Democrats alleged that the disparate treatment was a result of partisan divergence rather than Florida's unique circumstances (Daley 2018). The administration subsequently 
walked back the promise of an exemption for Florida, but the debate continues and numerous states are exploring legal efforts to frustrate the proposal's implementation (Muoio and French 2018).

As John Freemuth details in this issue, public lands have also been a hotbed for debate concerning federalism and the environment. Upon taking office, President Trump ordered review of twenty-seven national monuments designated since 1996 under the Antiquities Act (Eilperin 2017). Several public lands designations by President Obama proved particularly controversial. In December 2017, President Trump dramatically reduced the size of two Obama-era designations in UtahBears Ears and Grand Staircase-Escalante-citing the importance of local control (Gonzales, Siegler, and Dwyer 2017). Subsequently, evidence from a public records request litigated by The New York Times revealed that a desire to open certain public lands to oil and gas drilling motivated the decisions (Lipton and Friedman 2018). While litigation over the scope of presidential power to shrink designations under the Antiquities Act continues, the administration continues to review public lands boundaries for reshaping.

\section{The Supreme Court}

The judiciary remains an active arena for federalism. In its 2016 Term, which spanned October 2016 through June 2017, the Supreme Court did not issue any decisions fundamentally altering core areas of federalism jurisprudence such as commerce or the Tenth Amendment. Nonetheless, numerous decisions have important federalism implications. With the Court returning to full strength in April 2017 after Justice Neil Gorsuch's confirmation, it is poised to address a number of critical questions concerning federalism during its 2017 Term. While this section focuses on the Supreme Court, the reservoir of percolating issues is well stocked. As Nolette and Provost demonstrate in their article for this issue, state attorneys general remain active participants in the judicial arena, challenging various executive branch actions. Immigration and environmental policymaking are areas where important litigation is likely to reach the Court in the near future as we discussed previously. The rest of this part of the article discusses decisions implicating federalism from the Court's most recently completed term as well as important pending cases in its current term.

\section{The 2016 Term}

One consequential case joined the issues of federalism, race discrimination, and housing policy. In Bank of America v. City of Miami, 137 S. Ct. 1296 (2017), the Court allowed the city of Miami to bring suit against two banks for alleged violations of the Fair Housing Act (FHA). Miami argued that Bank of America and Wells Fargo issued riskier mortgages to black and Latino customers in violation of 
the FHA, resulting in harm to the city as a result of factors such as decreased tax revenue and increased spending on municipal services as a result of foreclosures. While it is common for states and municipalities to sue on behalf of their citizens as parens patriae, Miami alleged that it was an "aggrieved person" under the FHA. The Court held five-three that the city's alleged injuries were within the "zone of interests" the statute was designed to protect. Although the Court remanded the case for reconsideration of whether the banks' alleged discriminatory lending practices actually caused the city's financial injuries, allowing municipalities to seek recovery under the FHA has important federalism implications.

The Court decided two important redistricting cases. These cases demonstrated the Court's willingness to grapple with redistricting and help set the stage for what promises to be an active 2018 on this front as discussed in more detail below. In Cooper v. Harris, 137 S. Ct. 1455 (2017), the Court held by a five-three vote that two of North Carolina's congressional districts were drawn to pack-in black voters in violation of the Fourteenth Amendment's Equal Protection Clause. North Carolina argued that one of the district's boundaries nonetheless satisfied strict scrutiny because it was drawn to satisfy the Voting Rights Act (VRA)—an argument the Court rejected. Writing in dissent, Justice Alito suggested that "if a court mistakes a political gerrymander for a racial gerrymander, it illegitimately invades a traditional domain of state authority, usurping the role of a state's elected representatives" (1490). Importantly, Justice Thomas provided a fifth vote for the majority.

In Bethune-Hill v. State Bd. Of Elections, 137 S. Ct. 788 (2017), the Court considered whether twelve Virginia legislative districts explicitly drawn to create a black voting-age population of at least 55 percent violated the Fourteenth Amendment's Equal Protection Clause. The three-judge district court upheld the constitutionality of each district. With respect to one of those districts, the Court held that the state's effort to comply with the VRA was sufficient for satisfying strict scrutiny. With respect to the other eleven districts, however, the Court held that the three-judge district court panel applied the wrong test and remanded for reconsideration. Specifically, the Court clarified two points of law. First, it noted that a plaintiff need not show actual conflict between a redistricting plan and traditional redistricting principles; rather, racial predominance can be shown through evidence with respect to legislative purpose or more circumstantial evidence concerning district lines or demographics. Second, the Court held that analyses regarding racial predominance in line drawing should be holistic rather than limiting the consideration of racial motive to the extent that plaintiffs identify deviations from traditional redistricting criteria specifically attributable to race.

The Court decided several preemption cases, but none make a major contribution preemption jurisprudence. In Howell v. Howell, 137 S. Ct. 1400 (2017), the Court held that the Uniform Services Former Spouses' Protection Act 
preempts a state court's order treating a portion of retirement pay waived to receive disability benefits as community property for division in divorce. In Kindred Nursing Centers v. Clark, 137 S. Ct. 1421 (2017), the Court held that the Federal Arbitration Act preempted a state court decision refusing to recognize the validity of arbitration agreements executed by individuals who held power of attorney, when federal law otherwise requires such agreements to be treated the same as other contracts. And in Coventry Health Care of Missouri v. Nevils, 137 S. Ct. 1190 (2017), the Court held that the Federal Employees Health Benefits Act preempts state law prohibiting private carriers providing insurance to public employees under the Act from seeking reimbursement (i.e., recovering payment received from another entity) and subrogation (i.e., transfer of a right to a thirdparty payment to the insurer who can then pursue recovery) after an insured wins judgment from a third party. All judgments were unanimous except Kindred Nursing, where Justice Thomas adhered to his view that the Federal Arbitration Act does not apply in state court proceedings.

With respect to decisions affecting state actions and policymaking, the Court decided several cases with First Amendment implications. In Packingham v. North Carolina, 137 S. Ct. 1730 (2017), the Court unanimously invalidated a state law making it a felony for registered sex offenders to access a social networking site known to permit use by minors. Although the Court recognized the state's significant interest in protecting minors from sexual exploitation, it found that North Carolina's regulatory approach was too broad. In Expressions Hair Design v. Schneiderman, 137 S. Ct. 1144 (2017), the Court considered the validity of a New York law prohibiting sellers from imposing a surcharge on credit card transactions while allowing the economic equivalent of offering a cash discount. Whereas the lower court held that the law permissibly regulated conduct as opposed to speech, the Court unanimously held that the law regulated speech by dictating how businesses communicate with respect to the discount/fee. However, the Court sidestepped the underlying constitutional question, remanding the case for reconsideration in light of the speech versus conduct distinction. This "quarter-loaf outcome" (1153), as Justice Sonia Sotomayor put it in a concurrence in the judgment joined by infrequent ally Justice Samuel Alito, may have reflected division on the underlying merits question absent a ninth justice. Turning to the religion clauses, in Trinity Lutheran Church of Columbia v. Comer, 137 S. Ct. 2012 (2017), the Court invalidated a state agency's decision to categorically deny churches access to grant money to purchase recycled tire material for playgrounds. Although the agency argued that its refusal was dictated by a state constitutional provision prohibiting any money from being "taken from the public treasury" and given "directly or indirectly in aid of any church" (2017, quoting the Missouri Constitution), the Court held seven-two that denial of access to monies otherwise available on a general basis violates the Free Exercise Clause. 
The Court also addressed an important question at the intersection of property rights and environmental protection - with widespread implications for states and municipalities. At issue in Murr v. Wisconsin, 137 S. Ct. 1933 (2017), was how to define the relevant unit of property when assessing a regulatory takings claim. As opposed to state seizure of property in a traditional takings dispute, a regulatory takings dispute arises when a landowner attributes government action to a loss in property value or economic use. The plaintiffs in Murr owned two adjacent lots abutting a river, and wanted to sell a single 1.25 acre lot. A regulation dictated that at least 1.0 acre be suitable for development to sell one of two commonly owned adjacent lots, but after unsuitable areas were subtracted pursuant to regulations designed to protect the river area plaintiffs were left with a 0.5 acre lot for development purposes. After being denied a variance by the county board, plaintiffs sought recovery for a regulatory taking. Finding that plaintiffs retained options for land use in the adjacent lots, the Wisconsin Court of Appeals held that the regulations did not deprive plaintiffs of all or substantially all economic value in the property. Plaintiffs, however, argued that the court improperly calculated value by combining both parcels rather than focusing on the parcel they were not allowed to sell.

States were active as amici in Murr. Eight states argued that aggregating the adjacent lots for valuation purposes was improper, preferring to base the decision on the fact that state law joined the parcels for development purposes. They contended that their interests as amici were "at its apex" due to the potential impairment of property rights for "citizens vis-a-vis the States" and "States as against the federal government" (Brief for Nevada et al. as Amici Curiae 2016, 1). Nine states, meanwhile, argued for aggregation, contending that their interests lie in balancing property rights with a desire to "protect the environment" and "ensure that development occurs in a balanced manner, benefiting both property owners and the larger community" (Brief for California et al. as Amici Curiae 2016, 1). State and municipal interests such as the Council of State Governments, National Association of Counties, National League of Cities, and U.S. Conference of Mayors also filed a joint amicus brief for the respondent. In a five-three decision, the Court ruled for the respondent and proposed a multifactor test to guide future decisions that includes considering how property is treated under state law, the property's physical characteristics, and the land's prospective value. Writing in dissent, Chief Justice John Roberts lamented that the new test "compromises the Takings Clause as a barrier between individuals and the press of the public interest" (1956).

Several of the Court's decisions have implications for how states implement the death penalty. The Court granted certiorari in McWilliams v. Dunn, 137 S. Ct. 1790 (2017), to determine whether a prior precedent clearly dictated that states must afford indigent defendants meaningful expert assistance independent of the 
prosecution. In what a four-justice dissent called "a most unseemly maneuver" (1802), the five-justice majority sidestepped this question but found that Alabama's provision of mental health assistance during the underlying capital proceedings "fell ... dramatically short" of the constitutional minimum (1801). In Moore v. Texas, 137 S. Ct. 1039 (2017), the Court vacated a Texas Court of Criminal Appeals decision to disregard contemporary guidelines for determining whether a capital defendant is intellectually disabled in favor of guidelines adopted by the Texas court in 1992. And In Buck v. Davis, 137 S. Ct. 759 (2017), the Court granted habeas relief for ineffective assistance of counsel after a psychologist testifying for the defendant, who is black, claimed that the defendant's race was "know[n] to predict future dangerousness" (769), thus aiding the prosecution in demonstrating a necessary element for a death sentence, which the jury subsequently imposed.

The Court also continues to actively use its "shadow docket," which refers to "a range of orders and summary decisions that defy its normal procedural regularity" (Baude 2015, 1), to dispose of important issues, and several of last term's summary decisions impact states. In Bosse v. Oklahoma, 137 S. Ct. 1 (2016), the Court unanimously vacated a decision by the Oklahoma Court of Criminal Appeals stating that the Court had "implicitly overruled" (2) a prior precedent holding that the Eighth Amendment prohibited the use of victim impact evidence unrelated to the crime at a capital sentencing hearing. The Court also unanimously vacated a decision by the Nevada Supreme Court in Rippo v. Baker, 137 S. Ct. 905 (2017), which it deemed had applied the wrong legal standard in declaring that a request for judicial recusal due to bias could not go forward absent evidence of actual bias, whereas the Court had previously indicated that such a claim could go forward under the Fourteenth Amendment's Due Process Clause when "the probability of actual bias ... is too high to be constitutionally tolerable" (907). And in Pavan v. Smith, 137 S. Ct. 2075 (2017), the Court summarily reversed an Arkansas Supreme Court ruling that a state requirement to list the name of a mother's male spouse on a birth certificate need not be applied to same-sex couples. In a six-three per curiam decision, the Court held that this was included in the "constellation of benefits" (2078) the state linked to marriage and was thus encompassed by the Court's ruling in Obergefell v. Hodges, 135 S. Ct. 2584 (2015). Justice Gorsuch dissented, joined by Justices Alito and Clarence Thomas, arguing that "the strong medicine of summary reversal" (2080) is not warranted where the outcome is not clearly dictated by Obergefell. Although the dissenters did not reach a conclusion on the merits, Justice Gorsuch's opinion offers an early signal of his position on questions concerning Obergefells application. On the other side, that Chief Justice Roberts joined the majority disposition is notable. 


\section{Percolating Issues}

With a full Court for a complete term for the first time since Justice Antonin Scalia's passing, the 2017 Term promises to be a blockbuster compared to recent years. Murphy v. National Collegiate Athletic Association, 16-476 (2016), is perhaps the most important case with respect to core federalism doctrine. It considers whether a federal law prohibiting states from authorizing sports betting unconstitutionally commandeers New Jersey-in violation of the Tenth Amendment and broader constitutional structure-in the wake of the state partially repealing its sports betting law. Perhaps the most salient case more generally, which also has important federalism implications, is Masterpiece Cakeshop v. Colorado Civil Rights Commission, 16-111 (2016). After being held on the Court's docket for nearly a year, this case considers whether a state's antidiscrimination law can be used to require a custom cake maker to provide service to a same-sex couple under the First Amendment's Speech and Free Exercise Clauses. In addition to the case's First Amendment implications, it promises to further the Court's development of jurisprudence on issues concerning discrimination on the basis of sexual orientation.

The Court's 2017 Term includes several other First Amendment cases with policy implications for the states. In Janus v. American Federation of State, County, and Municipal Employees, No. 16-1466 (2017), the Court revisits the issue of whether mandatory union fees violate the Speech Clause, a question on which it deadlocked in 2016 after Justice Scalia's passing. Thus, Justice Gorsuch's vote will presumably be decisive. In Minnesota Voters Alliance v. Mansky, No. 16-1435 (2017), the Court considers whether a Minnesota law prohibiting political badges, buttons, and insignia from being worn around a polling place on election day violates the Speech Clause. In National Institute of Family Life v. Becerra, 16-1140 (2017), the Court will address whether a California law requiring antichoice, state regulated clinics to provide information on issues such as state-funded abortion services violates the Speech and Free Exercise Clauses. The Court considers whether a plaintiff alleging retaliatory arrest under Section 1983 must plead and prove the absence of probable cause in Lozman v. City of Riviera Beach, 17-21 (2017), a question that arises out of a long-running dispute between a resident and city council. In Benisek v. Lamone, 17-333 (2017), the Court considers a First Amendment retaliation claim in the context of a Maryland redistricting dispute.

Several other redistricting and voting cases are on the Court's current docket. With respect to voting, Husted v. A Philip Randolph Institute, 16-980 (2017), examines whether Ohio's decision to trigger removal from its voter file after two years of inactivity is consistent with federal law. The most prominent redistricting cases are Gill v. Whitford, 16-1161 (2017), which raises a variety of questions concerning a state legislative redistricting plan in Wisconsin, and Benisek v. Lamone, which addresses 
claims of partisan gerrymandering regarding a congressional redistricting plan in Maryland. In addition to the substantive questions presented in these cases, the Court is considering whether partisan gerrymandering claims are justiciable-an issue that could have important implications for future litigation. The Court turns to the subject of racial gerrymandering in Abbot v. Perez, 17-586 (2017). Supporting Texas, seven states filed a joint amicus brief urging the Court to note probable jurisdiction and reverse the lower court's decision invalidating certain state congressional districts, warning that the district court decision could "throw[] elections into disarray" and have "widespread implications for States entering the 2018 election cycle and the coming 2020 redistricting cycle, destabilizing the democratic system in all States" (Brief for Louisiana et al. as Amici Curiae 2017, 1). Aside from these docketed cases, the Court also entered a partial stay of a lower court's decision invalidating districts in North Carolina. However, the Court declined to stay a Pennsylvania Supreme Court decision invalidating the state's congressional map under the Pennsylvania Constitution as the product of partisan gerrymandering.

Another case on the Court's current docket worth watching for its federalism implications is South Dakota v. Wayfair, 17-494 (2017). In Quill v. North Dakota, 504 U.S. 298 (1992), the Court reaffirmed a long-standing precedent that a state violates the dormant Commerce Clause when requiring out-of-state companies with no instate physical presence to pay taxes on sales to state residents. At issue in Wayfair is whether the physical-presence rule, which emanates from cases concerning the mail-order industry, should be jettisoned in an era where ecommerce plays an integral role in the marketplace. In support of South Dakota's effort to overturn Quill, forty-one states filed a joint amicus brief arguing that the status quo leaves them "in an increasingly untenable position," depriving states of "billions of dollars in tax revenue each year, requiring cuts to critical government programs" (Brief for Colorado et al. as Amici Curiae 2018, 1).

\section{Conclusion}

The key themes that characterized the state of American federalism in 2017-2018 included federal policy reversal, executive action, and state resistance. As we observed in last year's annual review, "unified government is not necessarily a panacea for increased legislative production" (Goelzhauser and Rose 2017, 308). With the Republican-controlled Congress largely sidelined by partisan infighting, the Trump administration stepped into the vacuum, with wide-ranging consequences for both the Obama administration's legacy and intergovernmental relations. In the absence of federal legislation on health care reform, immigration reform, and a host of other pressing issues, federal policy change emanated primarily from the White House. In a sense, these developments reflect the continuation of Obama-era trends; however, what is striking in the current 
political environment is that executive action continues to be so prominent in the context of unified party control of government.

State resistance to the Trump administration's agenda also took place largely outside the legislative arena. Taking a cue from the Republican attorneys general who had challenged the ACA, EPA rules, and other Obama-era policies in court, Democratic attorneys general stepped into the fray in 2017-2018 with scores of legal actions against the Trump administration, many of which were still making their way through the courts at the time of writing. "Once a staid backwater mostly seen as a political stepping stone," the office of the state AG has emerged as a major bulwark, playing "among the most pivotal roles slowing and stopping the march of the Trump agenda" (Neuhauser 2017). The prominent role of Democratic state attorneys general in fighting administration policies is, in part, a function of the Democratic Party's limited control of state legislatures and governorships-something that could change following the 2018 election.

\section{Notes}

The authors are listed in reverse alphabetical order but contributed equally to the article. The authors thank John Dinan and two anonymous referees for helpful comments on earlier drafts. S.R. thanks Ellen Lempres for research assistance and the Rose Institute of State and Local Government for support.

1. Colorado, Washington, Alaska, Oregon, California, Nevada, Maine, Massachusetts, and Washington, DC, legalized recreational use of marijuana through ballot initiatives.

\section{References}

Armour, Stephanie. 2018. States Look at Establishing Their Own Health Insurance Mandates. Wall Street Journal, February 4.

Baude, William. 2015. Foreword: The Supreme Court's shadow docket. New York University Journal of Law \& Liberty 9 (1): 1-47.

Bousquet, Steve. 2018. Rick Scott and Trump Administration Strike Deal: No Drilling off Florida Coast. Tampa Bay Times, January 9.

Brief for the States of California, et al. as Amici Curiae, Murr v. Wisconsin, No. 15-214 2016.

Brief for the States of Colorado, et al. as Amici Curiae, South Dakota v. Wayfair, No. 17-494 2018.

Brief for the States of Louisiana, et al. as Amici Curiae, Abbott v. Perez, No. 17-586 2017.

Brief for the States of Nevada, et al. as Amici Curiae, Murr v. Wisconsin, No. 15-214 2016.

Brown, Kate. 2018. Statement on Reports A.G. Sessions Will Rescind Federal Marijuana Policy. January 4. http://www.oregon.gov/newsroom/Pages/NewsDetail.aspx? news$\mathrm{id}=2499 \#$. Wk5eLhvnwiw.twitter 
Camera, Lauren. 2018. Concerns Mount Over K-12 Education Plans. US News and World Report, January 3.

Complaint. 2018a. United States v. California, Case No. 18-264. https://www.politico.com/f/? $\mathrm{id}=00000161-\mathrm{fe} 3 \mathrm{e}-\mathrm{d} 513$-a767-febf57c70002.

2018b. New York v. Pruitt, Case No. 1: 18-cv-1030. https://ag.ny.gov/sites/default/ files/suspension_rule_complaint.pdf.

Daley, Matthew. 2018. Democrats in Coastal States Cry Foul after Trump Rescinds Oil Drilling Plan for Florida. Chicago Tribune, January 10.

Davenport, Coral. 2018. In a Gamble to Make Climate Change a Political Win, a Governor Pursues a Carbon Tax. The New York Times, March 1.

DeVos, Betsy. 2018. Prepared Remarks by U.S. Secretary of Education Betsy DeVos to State Chiefs. March 5. https://www.ed.gov/news/speeches/devos-state-chiefs-we-can-we-mustdo-better-students

Eilperin, Juliet. 2017. Zinke Backs Shrinking More National Monuments and Shifting Management of 10. Washington Post, December 5.

Eilperin, Juliet, and Brady Dennis. 2018. EPA to Roll Back Car Emissions Standards, Handing Automakers a Big Win. Washington Post, April 2.

Executive Order 13768 of January 25, 2017. Enhancing Publica Safety in the Interior of the United States.

Fears, Darryl. 2018. Trump Administration Plan Would Widely Expand Drilling in U.S. Continental Waters. The Washington Post, January 4.

Gallup. 2017. Record-High Support for Legalizing Marijuana Use in U.S. October 25. http:// news.gallup.com/poll/221018/record-high-support-legalizing-marijuana.aspx

Goelzhauser, Greg, and Shanna Rose. 2017. The State of American Federalism 2016-2017: Policy reversals and partisan perspectives on intergovernmental relations. Publius: The Journal of Federalism 47 (3): 285-313.

Gonzales, Richard, Kirk Siegler, and Colin Dwyer. 2017. Trump Orders Largest National Monument Reduction in U.S. History. National Public Radio, December 4.

Grandoni, Dino. 2018. The Energy 202: Democratic Attorneys General have Launched 80 Actions against Trump Environmental Agenda. Washington Post, February 28.

Gurman, Sadie. 2018. Sessions: U.S. Prosecutors Won't Take On Small-Time Pot Cases. Associated Press, March 10.

Hobbs, Tawnell D. and Leslie Brody. 2018. Some Teachers Already have Guns. Wall Street Journal, February 22.

Holder, Sarah. 2018. As California Protects Immigrants, Cities Revolt. City Lab, April 3.

H.R. 3003. 2017. No Sanctuary for Criminals Act. 115th Congress.

Jordans, Frank, and Dorothee Thiesing. 2017. Defying Trump, U.S. Cities and States Pledge to Support Goals of Paris Climate Deal. The Chicago Tribune, November 11. 
Klein, Alyson. 2017. Trump Education Dept. Releases New ESSA Guidelines. Education Week Blog, March 13. http://blogs.edweek.org/edweek/campaign-k-12/2017/03/trump_ education_dept_releases_new_essa_guidelines.html

Kulisch, Eric. EPA Orders Revised CAFÉ Targets, May Revoke California's Waiver. Automotive News, April 2.

LePage, Paul R. 2017. Letter to the 128th Legislature of the State of Maine. November 3. https://docs.google.com/document/d/

1EGNlwYuGNmDZF8KZVzBaZrytzRQfIYXC29YeLo3zVSo/edit? usp\%3Dsharing

Lipton, Eric, and Lisa Friedman. 2018. Oil was Central in Decision to Shrink Protected Utah Site, Emails Show. New York Times, March 5.

Mooney, Chris, and Dino Grandoni. 2018. New York City sues Shell, ExxonMobil and Other Oil Companies over Climate Change. The Washington Post, January 10.

Muoio, Danielle, and Marie J. French. 2018. States Vow to Fight Offshore Drilling by Any Means at their Disposal. Politico, March 12.

Musumeci, MaryBeth, Robin Rudowitz, Elizabeth Hinton, Larisa Antonisse, and Cornelia Hall. 2018. Section 1115 Medicaid Demonstration Waivers: The Current Landscape of Approved and Pending Waivers. Kaiser Family Foundation, March 8. https://www.kff.org/ medicaid/issue-brief/section-1115-medicaid-demonstration-waivers-the-current-landscapeof-approved-and-pending-waivers/

Neuhauser, Alan. 2017. State Attorneys General Lead the Charge Against President Donald Trump. US News and World Report, October 27.

Newsom, Gavin. 2018. Statement: Lt. Governor Newsom on Federal Plans to Reverse Marijuana Policy. January 4. http://ltg.ca.gov/news.2018.01.04_FederalMarijuanaPolicy. html

Plumer, Brad. 2017. Just How Far Can California Possibly Go on Climate?. The New York Times, July 26.

Presidential Proclamation of September 24, 2017. Enhancing Vetting Capabilities and Processes for Detecting Attempted Entry Into the United States by Terrorists or Other Public-Safety Threats.

Rosenbaum, Sara. 2018. Experimenting on the Health of the Poor: Inside Stewart v. Azar. Health Affairs Blog, February 5.

Sanders, Linley. 2018. Marijuana Legalization 2018: Which States Might Consider Cannabis Laws This Year?. Newsweek, January 2.

Sanger-Katz, Margot. 2018. A Big Divergence is Coming in Health Care among States. New York Times, February 28.

Selsky, Andrew, and Tom James. 2018. Oregon Lawmakers Look Ahead to Capping Greenhouse Gasses. The Seattle Times, March 4.

Sessions, Jefferson B. 2018. Memorandum for All United States Attorneys. January 4. https:// www.justice.gov/opa/press-release/file/1022196/download 
Staggs, Brooke. 2018. Marijuana May Be Legal in California, But Cities are Creating their Own Cannabis Regulations - and Bans. Orange County Register, January 4.

U.S. Congressional Budget Office. 2017. Repealing the Individual Health Insurance Mandate: An Updated Estimate. November 8. https://www.cbo.gov/system/files/115th-congress2017-2018/reports/53300-individualmandate.pdf

U.S. Department of Education, Office of Civil Rights. 2017. Q\&A on Campus Sexual Misconduct. September. https://www2.ed.gov/about/offices/list/ocr/docs/qa-title-ix201709.pdf

U.S. Government Accountability Office (GAO). 2018. Medicaid Demonstrations: Evaluations Yielded Limited Results, Underscoring Need for Changes to Federal Policies and Procedures. GAO-18-220, January 19. https://www.gao.gov/products/GAO-18-220

Verma, Seema. 2018. Letter to Governor C.L. 'Butch' Otter and Director Dean L. Cameron. March 8. https://www.cms.gov/CCIIO/Resources/Letters/Downloads/letter-to-Otter.pdf 